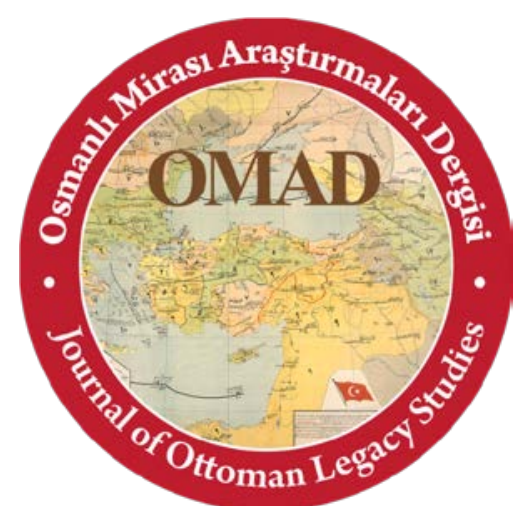

Osmanlı Mirası Araştırmalan Dergisi/Journal of Ottoman Legacy Studies

ISSN 2148-5704

www.osmanlimirasi.net

osmanlimirasi@gmail.com

Cilt 6, Sayı 16, Kasım 2019 / Volume 6, Issue 16, November 2019

\title{
COMPARATIVE HISTORICAL DEVELOPMENT OF IZMIR PORT FROM THE PERSPECTIVES OF PIRI REIS, SIBEL ZANDI-SAYEK AND THE SUPREME ASSEMBLY OF ECONOMICS $\left(1^{\text {th }}-20^{\text {th }}\right.$ CENTURY) Piri Reis, Sibel Zandi-Sayek ve Âli İktisat Meclisi'ne Göre İzmir Limanı'nın Karşılaştırmalı Tarihsel Gelişimi (16-20. yy)

\author{
Makale Türü/Article Types : Araştırma Makalesi/Research Article \\ Geliş Tarihi/Received Date : 27.09 .2019 \\ Kabul Tarihi/Accepted Date : $\quad 08.10 .2019$ \\ Sayfa/Pages : 573-590
} \\ DOI Numaras1/DOI Number : http://dx.doi.org/10.17822/omad.2019.143
}

\section{ŞENGÜL ŞANLIER}

(Dr. Öğr. Üyesi), Recep Tayyip Erdoğan Üniversitesi, Turgut Kıran Denizcilik Fakültesi, Deniz Ulaştırma İşletme Mühendisliği Bölümü, Rize / Türkiye, e-mail: sengul.sanlier@erdogan.edu.tr, ORCID: https://orcid.org/0000-0003-3676-6641

\footnotetext{
$\underline{\text { Atif/Citation }}$

Şanlıer, Şengül, "Comparative Historical Development of Izmir Port from the Perspectives of Piri Reis, Sibel Zandi-Sayek and the Suprame Assmebly of Economics (16 $6^{\text {th }}-20^{\text {th }}$ Century)", Osmanlı Mirası Araştırmaları Dergisi, 6/16, 2019, s. 573-590.
} 



\title{
COMPARATIVE HISTORICAL DEVELOPMENT OF IZMIR PORT FROM THE PERSPECTIVES OF PIRI REIS, SIBEL ZANDI-SAYEK AND THE SUPREME ASSEMBLY OF ECONOMICS $\left(16^{\text {th }}-20^{\text {th }}\right.$ CENTURY $)$
}

\author{
Piri Reis, Sibel Zandi-Sayek ve Âli İktisat Meclisi’ne Göre İzmir Limanı'nın Karşılaștırmalı \\ Tarihsel Gelişimi (16-20. yy)
}

\section{Şengül ŞANLIER}

\begin{abstract}
The more important the cities in the Ottoman Empire where the princesses grow, the more important the port cities, which are the commercial centers. The Izmir port studied in this paper has always been remarkable for features, and hinterland it has from the Ottoman period to the present. In order to follow the historical development of the port, three main sources have been taken as basis. The first work referred to in this study is "Kitâb-i Bahriye", written by Piri Reis in the 16th century. The second source used the book titled "Ottoman Izmir: The Rise of a Cosmopolitan Port 1840-1880" written by Sibel Zandi-Sayek. The last source is the report which was published at the end of the meeting of the Supreme Assembly of Economics held on December 15-19, 1931. In the report that gives information particularly on the status and import-export statistics of Izmir Port, the figures before and after the war were examined in detail in order to give an overall picture of the period. Using these sources as basis in this study, we tried to provide a broad perspective of the historical development and maritime trade of the Port of Izmir over three centuries in chronological order.
\end{abstract}

Keywords: Historical Development of Izmir Port, Piri Reis, Sibel Zandi-Sayek, Supreme Assembly of Economics, Maritime Trade

Öz: Osmanlı Devleti'nde şehzadelerin yetiştiği sancak şehirleri ne kadar önemli ise, ticaret merkezi olan liman şehirleri de o kadar önemlidir. Bu çalışmada konu edinilen İzmir Limanı, Osmanlı'dan bugüne kadar sahip olduğu imkânlar ve hinterlandı itibarıyla dikkat çekici özelliklere sahip olmuştur. Limanın tarihsel gelişimini takip edebilmek açısından üç ana kaynak temel alınmıştır. Çalışmada başvurulan ilk eser 16. yüzyılda kaleme alınan Piri Reis'in "Kitâb-1 Bahriye" adlı eseridir. İkinci kaynak, Sibel Zandi-Sayek tarafindan kaleme alınan "Ottoman Izmir: The Rise of a Cosmopolitan Port 1840-1880” adlı çalışmasıdır. Son kaynak ise, Âli İktisat Meclisi'nin 15-29 Aralık 1931 tarihli toplantısı sonunda yayımlanan rapordur. Spesifik olarak İzmir Limanı'nın durumu ile ithalat-ihracat değerlerinin yer aldığı rapora göre savaş öncesi ve sonrası rakamlar dönemin genel manzarasını ortaya koyması bakımından detaylı olarak incelenmiştir. Çalışmada bu kaynaklar dikkate alınarak, üç ayrı yüzyıl ve kronolojik sıra ile İzmir Limanı'nın tarihsel gelişimi ve deniz ticareti geniş bir perspektifle verilmeye çalışılmıştır.

Anahtar Kelimeler: İzmir Limanı'nın Tarihsel Gelişimi, Piri Reis, Sibel Zandi-Sayek, Âli İktisat Meclisi, Deniz Ticareti

\section{Introduction}

The Mediterranean has been one of the busiest sea-lanes in the world since ancient times. The sea owes its superiority to its topographic, oceanographic, climatic and geopolitical features. ${ }^{1}$ Surrounded by mountain ranges to the north, the Mediterranean region has indented

\footnotetext{
${ }^{1}$ Strong winds and storms are rarely observed in the Mediterranean. This facilitates the navigation of the ships together with the sea and land breezes and the currents flowing along the shore. Besides, the capes, peninsulas and the chains made up of islands lying across each other like a natural harbor make it possible to travel without losing sight of the land, which once facilitated the inexperienced navigation of ancient times. Güneş Girgin, Mediterranean Trade in Phoenicians, Selçuk University Graduate Schhool of Social Sciences, 2006, p. 15.
} 
and protruding coasts and various islands, peninsulas, bays and gulfs in different sizes. The sea is connected to the Atlantic Ocean by the Strait of Gibraltar and to the Black Sea and the Russian steppes by the Dardanelles, the Bosporus and the Marmara Sea. ${ }^{2}$ Therefore, the Mediterranean and the port cities of the Mediterranean, which have always been regarded as a commercial crossroads, have always been important throughout history.

As of the $16^{\text {th }}$ century, the Ottoman Empire emerged as an important force in terms of both navy and maritime trade. The Ottoman Empire annexed the Mediterranean lands after the Straits, Aegean and the Black Sea and began to have a say in the Mediterranean Sea trade. Izmir Port, which came under the control of the Ottoman Empire in the $15^{\text {th }}$ century and started to catch on with the western merchants as of the 16th century, has a very important geopolitical position as it is the gate of the Ottoman Empire opening to the world. ${ }^{3}$ In addition to having natural gulfs, Izmir Port is also the final destination of the Silk Road, which is another reason why the port is so important.

Piri Reis' Kitâb-i Bahriye [The Book of the Marine], which is one of the three sources this study is based on, was chosen as the primary source as it provides a rich body of information about maritime trade of that period. It is not a coincidence that the Port of Izmir, which started to be controlled by the Ottoman State in the $15^{\text {th }}$ century and began to catch on with the Western merchants as of the $16^{\text {th }}$ century, is examined in detail in Kitâb-i Bahriye. In his work, Piri Reis examined the Port of Izmir in detail by giving information on the city, its geographical and climatic characteristics and the commercial products in detail. In this sense, the book itself has integrity and a different methodology.

The second work we used in this study regarding the development of the Mediterranean maritime trade and port cities is the book titled "Ottoman Izmir: The Rise of a Cosmopolitan Port 1840-1880" written by Sibel Zandi-Sayek, which deals with Izmir and Izmir Port from a geopolitical and geo-strategic perspective in the context of the $19^{\text {th }}$ century city modernization. Zandi-Sayek, who designs a city monograph with her attention, point of view and approach, presents a panoramic photo of the Ottoman Port city of Izmir in the coming century. ZandiSayek scrutinizes the social and political causes of the changing life in the reform period of the Tanzimat, while also drawing attention to the effect of Izmir Port, which was under the influence of Levantines, on the city. She reveals in detail how the port played a leading role in the transformation of Izmir into a commercial center.

The third study is the report issued by the Supreme Assembly of Economics which included projections of the economic moves of the Turkish Republic which was newly established on the Ottoman territories. ${ }^{4}$ The report presents the proposals on the measures required to be taken to improve the Turkish ports made during the meeting dated December 1529, 1931, held by the Supreme Assembly of Economics which was founded under the prime ministry with the law that consisted of 14 articles on June, 25, 1927. The report includes data on the situation and import-export volume of the Port of Izmir which is considered as one of the major ports of Turkey due to its geographical position.

\footnotetext{
2 Yasemin Nemlioğlu Koca, "Pîrî Reis Eserlerinde Liman Şehirlerinin Özellikleri", Paper presented at the International Symposium "Piri Reis and History of Turkish Maritime", Ankara 2014, p. 135-48.

3 The Ottomans seized the ports of Syria and Egypt, which became the center of trade in the Mediterranean, and occupied the eastern Mediterranean coasts. İdris Bostan, Beylikten Imparatorluğa Osmanlı Denizciliği (Ottoman Marine Activities from Beylik to Empire), Istanbul: Book Publishing, Istanbul 2015.

${ }^{4}$ The Supreme Assembly of Economics was not an organization specific to Turkey because such organizations were also available in countries such as France, Germany, Italy, Poland, England, Spain and Greece. Fehmi Akın Serkan Bayraktar, "One Of The Economics Institutions Of The Early Republic: High Economic Council” Dumlupinar University Journal of Social Sciences, 29, 2011, p. 115-6; Özlem Yakt1 - Perihan Ünlü Soylu, "A Pioneering Consultation Organ On The Path of Economic Development: Supreme Assembly of Economics" Ankara University Institue of Turkish Revolution History Journal of Atatürk Yolu, 47, 2011, p. 680; Murat Koraltürk, “Higher Council of Economy 1927-1935”, Financial Approach, 7/23, 1996, p. 47-64.
} 
This study aims to examine the Port of Izmir with a chronological approach from the perspectives of Piri Reis, Sibel Zandi-Sayek and the Supreme Assembly of Economics and to offer a synthesis of three different perspectives on the period from the $16^{\text {th }}$ century to the early years of the Republic. The study also aims to contribute to the studies related to the history of maritime by presenting a broad framework for the effect of Izmir Port on the city.

\section{From the Perspective of Kitâb-i Bahriye}

Piri Reis, ${ }^{5}$ book titled Kitâb-i Bahriye contains information about the geographical features of the Aegean and Mediterranean coasts which Piri Reis saw during the voyages he had participated in as well as including the maps of these regions. ${ }^{6}$ In this sense, the book is a travel book. It can also be regarded as a guide prepared for sailors. There are many copies of the work that reach today. It is believed that a large number of copies were made from the first book he wrote in 1521 and the second book he wrote by enriching the content in 1526, especially to be used in the navy in the years following the death of Piri Reis. Kitâb-i Bahriye has its own methodology. In the maps, especially the mountains, which are the points of bearing in maritime, are shown to serve as a guide and the markings are supported with explanations. The parts of the ports including piers, moles, breakwaters, shipyards, boat yards, warehouses, lighthouses, etc. are drawn and the port services provided to the ships are explained. Galleonsgaliots are drawn in the offshore areas of the great port cities, and sailing vessels are drawn in smaller shallows.

The mountain ranges are colored using brown, red, dun, green, gray tones depending on their features. Coastal sand dunes and shallows are shown with red dots, deep places with black dots, and rocky areas in the sea with black plus signs (+). Plain areas are colored in a single color as a flat surface. With such details, the map is a pioneering work both geographically and oceanographically. In Kitâb-i Bahriye, Piri Reis put excessive emphasis on the rivers and drinking water resources that meet the water needs of sailors and pointed them out in his maps. ${ }^{7}$

\footnotetext{
${ }^{5}$ Piri Reis was born in Gelibolu, one of the major shipbuilding centers of the time and one of the naval bases of the Ottomans. Piri Reis (1465-1554) was a unique cartographer, marine scientist and a captain who left a mark on the naval history. Thanks to his uncle Kemal Reis who was a Chief Admiral, he found the opportunity to travel through various seas at a young age. "Google Privacy Policy," last modified March 28, 2018, https://www.biyografi.net.tr/piri-reis-kimdir/

${ }^{6}$ Piri Reis is also remarkable in that he was one of the leading figures who helped the Ottoman Empire turn the Mediterranean Sea into a Turkish lake in the $15^{\text {th }}$ century. During the 1499-1502 Ottoman-Venetian War, he attended the expeditions to the coast of Sicily, Corsica, Sardinia and France. Bayezid II, who heard Piri Reis's name during these battles, granted him the title of "Admiral". During the conquest of Egypt by Yavuz Sultan Selim, the famous sailor supported the conquest with his fleet. He presented the maps he had drawn to Yavuz Sultan Selim while they were in Cairo and gained the sultan's interest and appreciation. He returned to the place where he was born after the Egyptian campaign and began to engage in science. During the reign of Suleiman the Magnificent, he participated in the expedition to the Rhodes. He presented his famous book Kitâb-i Bahriye, which he completed in 1527, to the Suleiman the Magnificent through Pargalı Ibrahim Pasha. Due to his book, the sultan honored and supported Piri Reis. Kemal Arı, "İzmir'de Deniz Ulaşımı ve Ticaretinin Kent Kimliğinin Oluşumu Üzerindeki Etkileri” Dokuz Eylül University Maritime Faculty Journal, 3/1, 2011, p. 6. ; Kemal Ar1, "Türk Deniz Ticareti Tarihi Sempozyum V: Piri Reis-Turkish Maritime Trade History Symposium V: Piri Reis.” Journal Of Modern Turkish History Studies, 13/26, 2013, p. 301-315. He participated in various expeditions, especially the one undertaken to transfer the Muslims fleeing from the oppression in Spain from Andalusia to the coasts of North Africa. In addition to being a mission for Piri Reis, these expeditions were also a rare source of information for the books he would write and the map he would draw. After this period during which he obtained unique information about maritime and seas, he continued informing both the sailors and the Ottoman administrators about the undiscovered regions of the world, thus making the Ottoman presence in the seas permanent. Hüseyin Gazi Topdemir, "Bilim Tarihçisi Gözüyle Piri Reis Bilim Tarihçisi Gözüyle Piri Reis” TUBA Günce, July 45, 2013, http://www.tuba.gov.tr/upload/files/gunce/45_072013_1302-9541.pdf.

${ }^{7}$ The side of the area called "Kösten Island” towards the Qibla is shallow and has anchorages. On this island, there is a cistern on the side of the monastery towards the direction southeastern wind is blowing facing towards the Qibla. The cistern was built in the time of Christians and it serves as a drinking water resource. This cistern was built on the marble pillars like the Binbirdirek Cistern in Istanbul. People go inside the cistern and try to find the accumulated rainwater. There is another cistern besides this cistern. Drinking water is obtained from these two
} 
The rivers are considered as a part of the coastal strip, they are depicted by thick dark lines and their local and known names are written. The lagoons are shown as black spots, while the lakes are shown as blue closed bodies of water. In the Kitâb-i Bahriye the villages, towns and cities on the coastal strip are described by their historical background. Besides, fortresses and city walls around the cities, ruins, bridges, windmills, aqueducts, canals, agricultural areas and water wells are also shown in detail in the maps. ${ }^{8}$

It is always an advantage to know port and port cities in maritime trade and to have detailed information about climate and environmental conditions. Piri Reis mapped the Aegean and Mediterranean coasts with explanations about their geographical characteristics. The major ports and trading cities of that period were drawn in Kitâb-i Bahriye in a much more detailed way than the other cities by showing the functional areas (Figure 1). ${ }^{9}$ A more detailed description of port cities in the works of Piri Reis is an indication of the intensity of the Mediterraneansea trade during the $15^{\text {th }}-16^{\text {th }}$ centuries. Given the lack of technical and technological opportunities in the $16^{\text {th }}$ century, the importance of these maps is better understood. The importance of sea transportation and ports becomes more apparent when considering that the long-distance road transportation remained incapable during the period when the book was written.

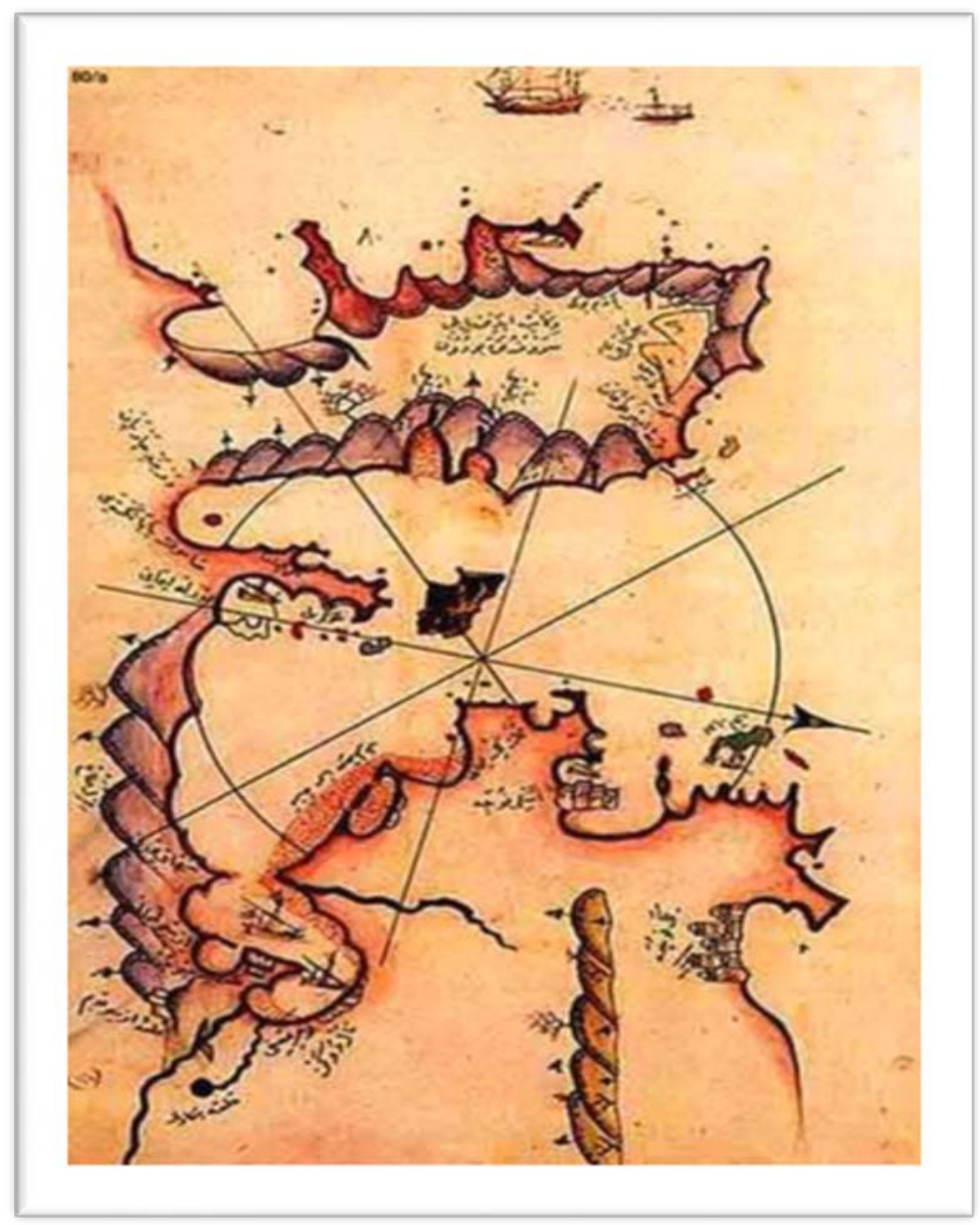

Figure 1. Ports of Izmir and Foça

cisterns”. Piri Reis, Kitâb-i Bahriye, Türkiyre Teknoloji Takımı Vakfi-Turkey Technology Team Foundation (TTT), Istanbul 1988.

${ }^{8}$ Y. Nemlioğlu Koca, agm., p. 135-48.

${ }^{9}$ P. Reis, age., p. 346. 


\subsection{Ports of Izmir and Foça in Piri Reis' Kitâb-i Bahriye}

Located on the left side of the Gulf of Izmir, the Port of Izmir is Turkey's second largest trade port after Istanbul. It stands out due to its fortress which belongs to the ancient city of Ephesus. Due to its geopolitical position, the port has maintained its significance since the Venetians and Genoese emerged in the maritime trade for the first time.

In his book, Piri Reis first mentions the Port of Foça. When describing the old and new Ports of Foça, he draws attention to the competition between the Venetian and Genoese merchants. According to the information he gives, the Genoese merchants built the New Port of Foça against the Venetians who built the Old Port of Foça. Having commercial concerns is the main reason for this competition. Although the New Port of Foça was built, Piri Reis notes that this port is not suitable for anchoring because it is open to the effects of the northeast and north winds. He says, for this reason, large vessels coming into this port are moored in the area around the Cape Taslik and Karaburun which is a more sheltered area located two miles away. Again, he points out that Orak Island and the Cape Uzun En are in a better location for anchoring. ${ }^{10}$

Piri Reis compares the ports of New Foça and Old Foça before giving detailed information about Izmir Port and he says: "The Port of Old Foça port is a unique natural harbor. It can accommodate a hundred of ships. Large ships arrive in front of the fortress. The ships lie longitudinally alongside the shore. Galiots wander around the eastern part of the fortress to moor. The fortress is surrounded by sea on three sides. It is connected with the land only on the one side. This port has two sub-districts. The place called Tekir Bahçesi is shallow, so boats cannot come closer to the shore. The second sub-district is Keklik Port. It is a natural harbor whose Qible side is shallow.

While giving information about the Port of Izmir of that time, Piri Reis points out that the small ships can proceed to the front of the fortress. This part called Inner Port is a 1-mile wide. This width is quite sufficient for the ships of that period. Here, there is a stony barrier called "Gammaz Taşı". The ships are made fast here. Heavy-lift vessels, which cannot come closer to the fortress due to the narrow width of the Inner Port, lay alongside the shallow area called Kum Kazı $\breve{g} 1$ and drop their anchor here (Figure 2). ${ }^{11}$ The freshwater resources found here are the reasons why sailors prefer to drop their anchors. Anchored ships in this area usually load grapes and other food products.

In addition to the Port of Izmir, Piri Reis also indicates that there are many small ports and bays especially towards Foça, putting particular emphasis on Island Yolluca and Eğri Port. Island Yolluca is the area between Izmir and Foça, which serves as a shelter for large vessels especially in winter. Since the fish garth is narrow here, ships drop their anchor against the stars and are made fast to the shore. Eğri Port is a natural harbor close to the Island of Kösten. It is also called the Gulf of Çarpan. Because it is a natural harbor, it is one of the places frequently visited by ships. Other than these two, the Bays of Sögüt, Bonito and Badem are especially suitable for ships called "çektiri". ${ }^{12}$

Piri Reis' work is based on direct knowledge and is mostly geographical and oceanographic. His work does not focus on the sociological, economic and geopolitical effects

\footnotetext{
10 "Cape Taşlık provides a good berth. Large ships can get into. Ships lie in front of the fortress which indicates the Qibla direction of the cape. There is a large stone at a distance of half a mile to the cape. Large vessels pass through between that stone and the cape, the sea is deep there”. P. Reis, age., p. 327.

${ }^{11}$ P. Reis, age., p. 347.

${ }^{12}$ Çektiri, çekdiri or çektirme is the name given to a historical ship type which includes both rowing and sailing ships. It includes many types of ships such as galiots, karamursel and bastarda. Some ships smaller than galiots known as "Küçük çektirme” gradually began to be called "çektirme”. Occasionally, the words cektiri and kadirga (galiot) are used synonymously. İdris Bostan, "Kadırga'dan Kalyon'a: XVII. Yüzyılın İkinci Yarısında Osmanlı Gemi Teknolojisi'nin Değişimi”, Osmanlı Araştırmaları (The Journal Of Ottoman Studies), 24, 2004, p. 66-86.
} 
of ports and port trade. Piri Reis does not directly take into account the demographics of the port cities and the historical dimension of their commercial activities. His main purpose is to give some basic information necessary for ports, port cities and a safe maritime trade. For this reason, we can say that Sibel Zandi-Sayek filled the missing parts of the book regarding Izmir. Sayek considered it more appropriate to examine the Port City of Izmir in the context of urban relations. It is chronologically worth resuming the search on Izmir and Izmir Port two centuries after Piri Reis.

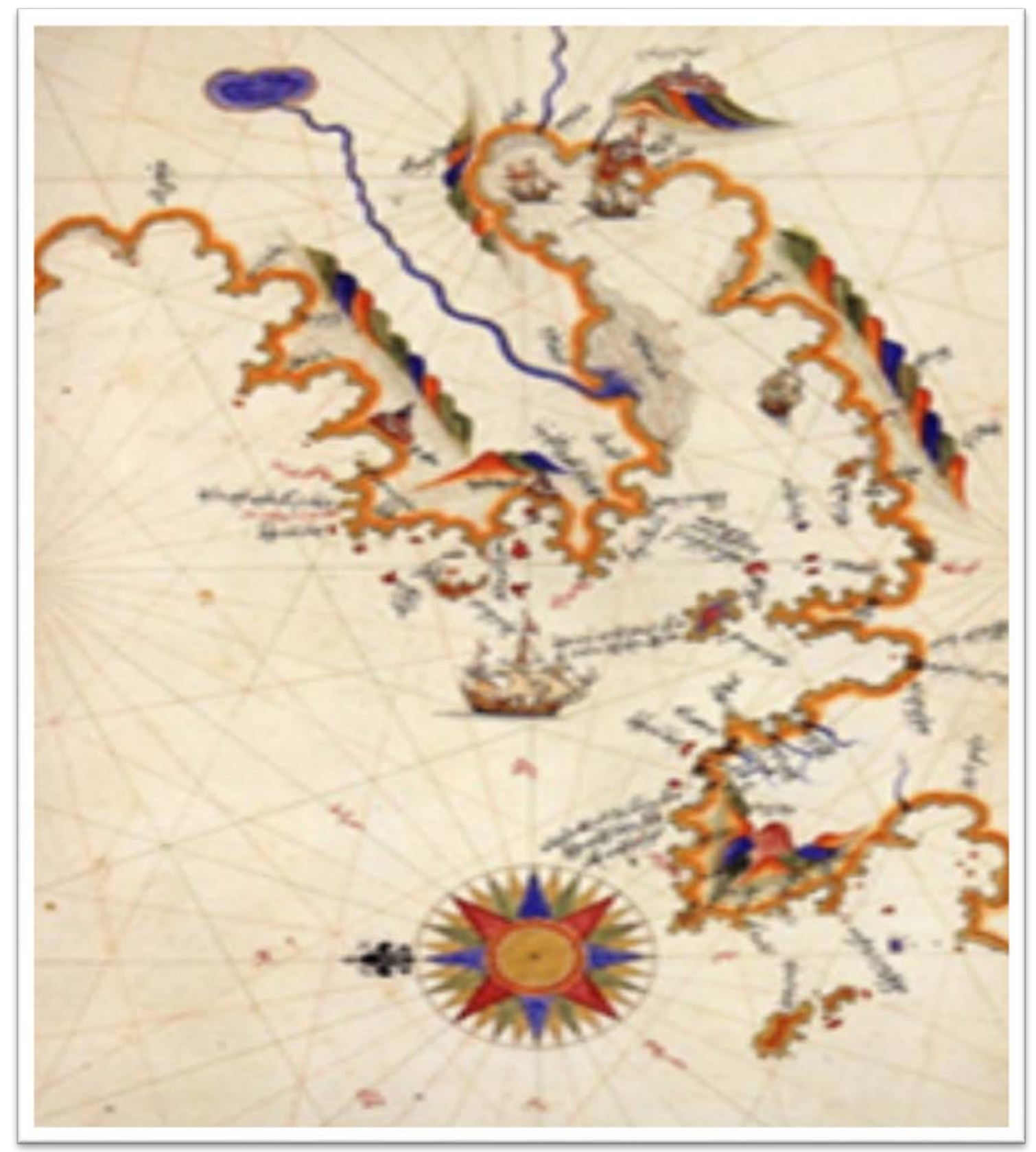

Figure 2. Port of Izmir and Its Surroundings 


\section{Izmir and Izmir Port Based on the Findings of Sibel Zandi-Sayek}

Sibel Zandi-Sayek, an architect and art historian, wrote a comprehensive book in which she examined the reflections of Ottoman modernism that started with the Tanzimat reform era on Izmir by using a different methodology focusing on city monograph and local people.

In her book, Zandi-Sayek discusses Izmir and Izmir Port in the context of $19^{\text {th }}$-century urban modernization with a geopolitical and geo-strategic view. ${ }^{13}$ She addresses the conditions of the period, the actors who had a role in the change and the social, political, commercial and religious factors in accordance with the perceptions of the period. She describes how rituals in the Ottoman society changed in terms of shaping life during the periods of change and how habits that emerged through the intervention of modernism transformed. Given the findings of the author, we can say that she actively depicts the struggle of the subjects of bureaucracy, bourgeoisie, military and merchants for life, while daily life, which is the passive object of life, continues in a monotonous way.

Zandi-Sayek tells us that the city's internal dynamics are as influential as the conditions of the period for the change and transformation of Izmir. Therefore, her most important argument is that diplomats, merchants and ethnic groups initiated the Ottoman modernism in a certain harmony. Since Zandi-Sayek examines Izmir as a city aesthete rather than a historian, she emerges as an observer looking at the city from different perspectives, not from a classical chronological viewpoint. When the book is examined in terms of its internal momentum, it is possible to see, depending on the wholeness of complex relations, demography, city development, intense global interaction and all the aspects of the Ottoman central government, which left its mark on the period.

One of the factors that makes Zandi-Sayek's book different is the sensitivity that it shows while revealing the references and the properties of that period. In her work, Zandi-Sayek uses all kinds of printed newspapers, administrative resources and resources in other languages obtained from the residents and visitors of that period as well as bureaucratic records, consular reports, historical guide books and geographical materials together in a skillful manner. Such a skillful use of resources moves the book to a surprising and precious point in terms of narrative composition.

In the first part of his book, Zandi-Sayek examines the Ottoman citizenship and the legal process that developed with the Tanzimat reform period. She addresses the concept of citizenship, the separation of Muslims and non-Muslims and the consequent living conditions and taxation. The second and third parts address the social and political actors and evaluate alliances within the framework of interest-based relationships. Reform expectations of the $19^{\text {th }}$ century, new demands for rights and the role of central government and administrative bodies are covered in these sections. Economic relationships, based on interest and their reflection on social life, are handled in a certain way. In the last part, she interprets the processes of global modernization as well as sovereignty, citizenship and other modern formations of other regional regimes. The innovations that started with the Tanzimat reform period, the contribution of local factors and the observations about the situation of the developing city and the changing life are given from a detailed point of view. The illustrations, images and lines used in the chapters are striking in that they reveal the attention paid to the subjects studied.

\subsection{Geo-Strategic Importance of the Port of Izmir}

The port city Izmir has been one of the important trade centers of the Mediterranean throughout the history due to its unique characteristics. Due to its location, it had been the "Protoss Asia" of the Romans, "The Jewel of Ionia" of the Ionians and the "Minor Asia" of the

\footnotetext{
${ }^{13}$ Sibel Zandi-Sayek, “Ottoman İzmir The Rise of a Cosmopolitan Port, 1840-1880”, University of Minnesota Press, Minnesota 2012.
} 
Turks prior to the Ottoman Empire. With its transportation network and port opening out to the West during the Ottoman period, it has always been a popular city.

With its pluralist society structure, the Ottoman Izmir had always been enshrined in the empire. In the late $16^{\text {th }}$ and early $17^{\text {th }}$ centuries, the capital city of Istanbul became a central city with all its characteristics. While Istanbul was a structure consisting of administrative and military institutions, Izmir, the emerging and rising port of the Mediterranean, became one of the busiest ports of trade with Europe. In the mid- $19^{\text {th }}$ century, the Port of Izmir, the gateway of Asia Minor in the Mediterranean Sea, became a colorful face of commercial life as a result of a tremendous physical change. During that period, the Port of Izmir became very popular due to its certain characteristics. The modern area equipped specially for international steam vessels, the railway lines, land transportation and hinterland features significantly changed the nature and volume of commercial activities in the port. The 2-mile-long port area became the new face of the city with its promenades, opening the door to new possibilities and a multicultural structure. ${ }^{14}$

In the $19^{\text {th }}$ century, Izmir became the capital of economic and cultural leap with its banks, postal services, commercial institutions and organizations, product storage facilities, dry food storages and social places such as hotels, commercial clubs, theaters etc. With its renewed and expanding opportunities, Izmir Port attracted the attention of merchants involved in large-scale trading. Izmir became a modern and renewed city sought after by merchants due to these characteristics. The leading figures of the city - from merchants involved in large-scale trading to civil servants - kept up with the changing face of the city and changed the position accordingly. After becoming a cosmopolitan and modern city thanks to its international port, Izmir became the new face of the $19^{\text {th }}$ century. Accommodating immigrants, seasonal workers, temporary sailors and communities with diverse ethnic, religious and national backgrounds, Izmir Port became the second largest city of the Ottoman Empire after Istanbul, with a population approaching nearly two hundred thousand between 1840 and 1880.

According to many European observers, the Ottoman Izmir did not accommodate itself to the Eastern culture very easily, but was always a different city with its streets, squares and bazaars, mostly reflecting the European Christian world. ${ }^{15}$

During the period from the $17^{\text {th }}$ century to the $19^{\text {th }}$ century, two places in Izmir became the heart of trade. One of them is the bazaar and the other is mahalle-i efrenc (Frank Quarter). The bazaar was an area that consisted of narrow streets arranged in the shape of a horse head towards the old port in the mid- $19^{\text {th }}$ century. The stores were narrow and single, resembling the shape of an old inn. Inns were the leading places where trade activities were practiced in the Ottoman Empire. A part of the domestic market and daily needs were met in these inns. On the contrary, the Frank Quarter was planned as a center for larger scale commercial affairs, and international trade was managed there. Offices and bureaus of merchants involved in large scale trade, modern hotels and cafes, hospitals and restaurants were usually in the vicinity. The streets of Frank Quarter opening to the inner port and its roads leading to the shore are multicultural and multilingual centers where commercial activities were intense. The British Pier was considered as an advantageous arterial road because of its proximity to Bahriye and the Bazaar. Despite its prestigious and important advantages, it was not a very large area. ${ }^{16}$

In the mid- $19^{\text {th }}$ century, Izmir's international trade volume and population increased unexpectedly. The main reason for the change was the Tanzimat Fermanı (Imperial Edict),

\footnotetext{
${ }^{14}$ S. Zandi-Sayek, age., p. 5-20.

${ }^{15}$ Forming its own physiognomy with its population structure, culture and lifestyle, Izmir was called "Gâvur İzmir" (infidel Izmir) at that time. According those calling the city Infidel Izmir, the city was one of the cities "betwixt" East and West. Due to its identity, Izmir is an extremely mixed, transitional and multicultural Eastern Mediterranean port city. S. Zandi-Sayek, age., p. 8-9.

${ }^{16}$ S. Zandi-Sayek, age., p. 9-15.
} 
which was declared in 1839. With this imperial edict, serious changes were made in many areas, from bureaucratic to military and judicial structures. With this innovation that made the port city of Izmir different, the essential elements that constituted the core of the city were restructured with a new concept. The Tanzimat regime introduced new regulations regarding criminal and appeal cases (court of appeal) between Muslim and non-Muslim people. It is observed that secular courts came into play regarding the issues such as taxes, income etc. in this period and the minorities were able to apply to the commercial court of when necessary. The first examples of this change can be seen in Izmir. In this sense, Izmir bureaucracy had a pioneering role regarding the rights bestowed on foreigners with regard to issues such as income tax and real estate. The Ottoman Law of Nationality, which was enacted in 1869, further strengthened this situation and the issue of the rights of property and succession granted the Ottoman citizens with foreign nationality was clarified. ${ }^{17}$ With the port facilities extended in the 1870s, Izmir established a direct and regular trade line with other Mediterranean ports such as London, Marseilles and Alexandria where sea trade was heavily practiced. New shipping routes and railway operations in this period affected the international activities of the port positively. ${ }^{18}$

The developing and growing nature of Izmir Port depended on the fact that the legal and commercial concerns in that period were removed. The role of these developments in making foreign merchants feel bureaucratically safe cannot be denied.

Given the export products of the port, Izmir had a high yield of cotton, raisins and cereals. The city had become a destination frequently visited by has merchants from Germany, France, Genoese and Venetian since the 1600s. The records show that silk and other textile products coming from places such as China, Aleppo and Bursa were shipped to Europe during that period. ${ }^{19}$

According to an agreement made between Ottoman and British governments in 1581, the British Levant Company ${ }^{20}$, established in London, is known to have held almost a "monopoly" in Izmir Port. ${ }^{21}$ Despite the objections of the French and Venetian merchants, the Ottoman Empire granted significant concessions to the British with this agreement. ${ }^{22}$ The consulates, opened in Izmir in parallel with the maritime trade since the $17^{\text {th }}$ century, were the result of the interest taken by the other countries in this port. In this period, Izmir Port's capital was in the hands of Greek, Armenian and Western merchants.

17 İbrahim Serbestoğlu, "Ottoman Nationality Law as an Example of a Forced Modernization”, Osmanlı Tarihi Araştırma ve Uygulama Merkezi Dergisi OTAM, 29, 2011, p. 205.

${ }^{18}$ S. Zandi-Sayek, age., p. 12-20.

${ }^{19}$ S. Zandi-Sayek, age., p. 9-15.

${ }^{20}$ The Levant Company was a privileged company established for the trade between England and the Levant Region of the Ottoman Empire. The company was established in 1581 by some British merchants who obtained the permission of Queen Elizabeth I. The aim of the company was to do business with the commercial centers in the Levant rather than colonizing. The company's first center was Aleppo. The company also established commercial relations with cities like Istanbul and Izmir. M. Epstein, “The Early History of The Levant Company”, New York: E. P. Dutton \& Co, 1981, p. 5-13.

${ }^{21}$ Izmir developed much faster than the other Levantine cities after the $17^{\text {th }}$ century and had its prime especially between the $17^{\text {th }}$ and $19^{\text {th }}$ centuries. For this reason, many travelers to Izmir referred to the city in their travel notes as "the capital of the Levant", "the brightest trading city of the Levant", "the most important commercial center of the Levant", "the pearl of the Levant", "Marseilles of the Anatolian coasts" and "Marseilles on the shores of Asia Minor”. Muharrem Yıldız, "İzmir Levantenleri Üzerine İnceleme”, TURAN: Stratejik Arastirmalar Merkezi, 4/13, 2012, p. 36-54.

${ }^{22}$ During the reign of Yavuz Sultan Selim, the first capitulations obliged the Genoese, Sicily and Ankona trading vessels to raise a French flag when they were in Ottoman waters, while the second capitulations obliged the British, Venetian and Portuguese trade vessels to do so. Thus, France has gained the upper hand over the Venice which dominated trade in the Eastern Mediterranean. When France began to fall under the Spanish influence, a capitulation agreement was signed with Britain since the British took a step to sign such an agreement. Ertuğrul Acartürk - Ramazan Kılıç, "The Analysis of the Capitulations in the Ottoman Empire from a Economic and Political Perspective”, Hacettepe University Journal of Economics and Administrative Sciences, 29/2, 2011, p. 4-9. 


\subsection{Structural Change in Izmir Port and Its Reflections on the Port}

In the third chapter of her book, Zandi-Sayek reveals how Izmir Port changed in the last quarter of the $19^{\text {th }}$ century and gives valuable information especially about the shaping of the coastal area. The information she gives based on the notes of the famous French geologist and traveler Louis de Launay is important in terms of reading the period more accurately. According to the traveler's findings, it is not possible to separate Izmir Port from the irregular interiors of the city. The old port in the 1850s was quite inadequate and behind the times. The roads leading to the port were irregular, rough and muddy. Although the government and the municipality decided on a structural change, they were not able to pull it off economically and to modernize it in a style appropriate to the era. For this reason, it was decided to transfer the port to a private entity through the "build-operate-transfer" model by taking account of the public interest. Following this decision, the port's modernization project was transferred to British companies that were previously granted certain privileges. This company transferred inancial and technical expertise of the project to the French company Dussaud Brothers (Dussaud Freres). ${ }^{23}$

The port project was started in December 1867, and although it was planned to take slightly longer than 4 years, it could only be completed in $1880 .^{24}$ The initial costs of the project were calculated at 6 million francs, or $£ 240,000$. 250,000 francs were reserved for additional work, bringing the total to $£ 250,000$. The project started at the imperial barracks and ended by the wharf of the Aydin railway station at the Pointe. In other words, it was constructed on a line from one end of the city to the other. ${ }^{25}$

Within the scope of the project, a quay $18 \mathrm{~m}$ wide and two artificial harbors were constructed with 1,250 m of stone breakwaters. One of these artificial harbors, known nowadays as the Inner Harbor and at the time as "port d'abri", was completely sheltered and covered 50\% of the total area. The other is smaller and less sheltered. Because it was open to the sea at the southern end and had a structure exposed to south-westerly winds. A $300 \mathrm{~m}$ breakwater running south-west from the south-western section of the bigger harbor was formed. Large coal bunkers were built on the breakwater at this point. The new customs building covering an area of 9000 $\mathrm{m}^{2}$ was constructed on the breakwater on the southern side of the inner harbor. The other part of the quay from the imperial barracks to the northeast end of the Inner Harbor included buildings for administration of the port such as post office, hospital and passport control center. The rest of the quay was planned as a promenade. ${ }^{26}$

The harbor was protected by a breakwater with a total length of $1250 \mathrm{~m}$ designed as an irregularly shaped triangle. The length of the south side of this breakwater was $200 \mathrm{~m}$, the length of the western side was $450 \mathrm{~m}$ and the length of the northern side was $400 \mathrm{~m}$. The northern side of the harbor was broken by a 100 m gap to enable ships to enter (Figure 3). ${ }^{27}$ The water was $10-12 \mathrm{~m}$ deep at the port center and 6,5m deep by the breakwater. This depth was sufficient for ships to anchor in it. The project also included the construction of a retaining wall made of cut stones and extending $4 \mathrm{~km}$ along the shoreline and $15 \mathrm{~m}$ above sea level.

\footnotetext{
${ }^{23}$ The quay was actually a British project. The company that undertook the project was established in 1868 and had a capital of 2.5 million francs or $£ 100,000$. The capital was made up of 5,000 shares of 500 francs each. The initial concessionaires of the project were J. H. Charnaud, A. Barker and G. Guarracino. In addition, the board of directors of the Smyrna Quay Company were among the shareholders. Elena Frangakis-Syrett, "The making of an Ottoman port-The quay of Izmir in the nineteenth century”, The Journal of Transport History, 22/1, 2001, p. 28.

${ }^{24}$ The reason why the project was completed so late was that there were problems in the other contemporary infrastructure projects such as the Izmir-Aydin railway line and the city's gasworks. For example, while the Smyrna Gas Company was laying its pipes it inadvertently severed the water and sewer pipes to many of the town's dwellings. Therefore, the company had to pay more or less indemnification, which made things difficult E. Frangakis-Syrett, agm., p. 29.

${ }^{25}$ The actual costs were higher. British sources show that the total was $£ 400,000$. E. Frangakis-Syrett, agm., p. 28.

${ }^{26}$ E. Frangakis-Syrett, agm., p. 27.

${ }^{27}$ E. Frangakis-Syrett, agm., p. 26.
} 


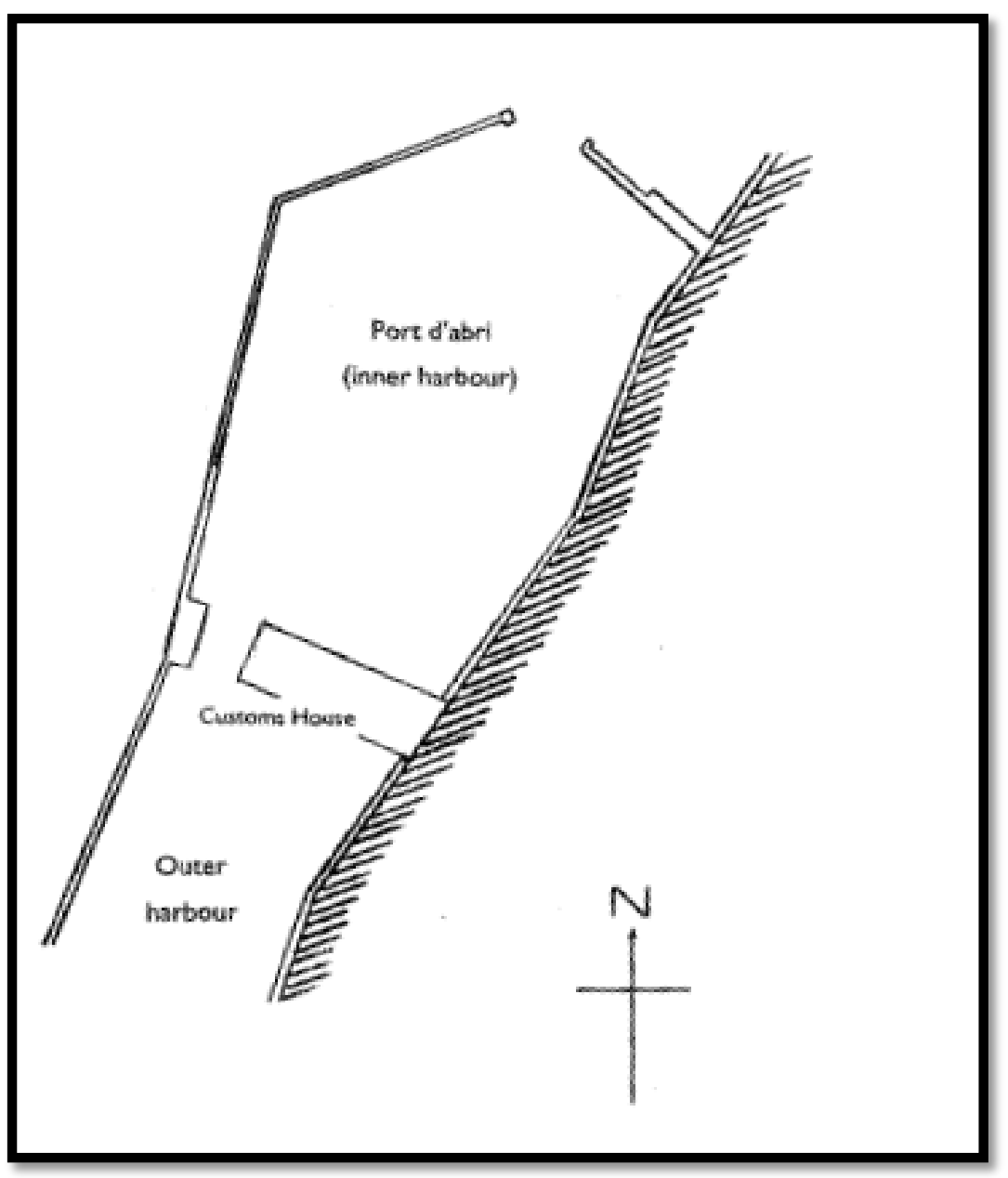

Figure 3. The Port of Izmir (1909)

The Izmir port project was not only limited to the arrangement of the quay area, but also included certain structural changes in the land. One of the integrated objectives of the project was to provide a more comfortable and profitable way to launch the goods brought to the port by railway to the international market. For this purpose, a dual-track tramway was built that led from the Customs House to the Aydin railway station. In addition, the French firm had paved the roads leading to the quay as well as constructing a road parallel to it, known as the rue Parallèle. Compared to the rest of the city, these streets are extraordinarily spacious, better furnished and lighter. The white-stone and stucco buildings and new work places established provided the city with a brand new appearance. The project of renovating Izmir Port was an enormous technological and entrepreneurial wonder that increased the city's regional competitive power at the time; because the project required a difficult and expensive underground sewage system. With the newly constructed sewage system, the installation of a sewage pipeline with a total length of $200 \mathrm{~m}$ from the city to the Customs House was completed. ${ }^{28}$

It is understood from the table 1 of imports and exports through the port between the years 1867-1912 that the trade volume of Izmir Port rapidly increased and the port began to attract the attention of foreign traders more after the innovations (Table 1$)^{29}$.

\footnotetext{
${ }^{28}$ S. Zandi-Sayek, age., p. 15.

${ }^{29}$ E. Frangakis-Syrett, agm., p. 35.
} 
Table 1. Value of the Trade of Izmir

\begin{tabular}{ccc}
\hline Year & Exports (£) & Imports (£) \\
\hline 1867 & $4,455,170$ & $3,404,000$ \\
1870 & $3,620,450$ & $3,007,000$ \\
1873 & $4,499,000$ & $4,518,000$ \\
1876 & $4,629,590$ & $2,859,934$ \\
1879 & $4,406,699$ & $4,755,609$ \\
1882 & $3,841,862$ & $3,215,921$ \\
1885 & $4,315,340$ & $2,692,947$ \\
1888 & $3,867,083$ & $2,710,445$ \\
1891 & $3,927,182$ & $2,985,851$ \\
1894 & $4,323,839$ & $3,158,263$ \\
1897 & $3,100,000$ & $2,250,000$ \\
1900 & $4,157,405$ & $2,538,000$ \\
1903 & $4,833,931$ & $2,802,000$ \\
1906 & $4,973,412$ & $3,547,000$ \\
1909 & $5,036,000$ & $3,508,000$ \\
1912 & $4,000,000$ & $3,738,000$ \\
\hline
\end{tabular}

Dussaud, as the owner of the "Porte Dussaud" project, negotiated with the Ottoman government and the concession was extended to 1912. In other words, the Ottoman Government transferred the operating rights of Izmir Port to this company for 15 years. This project, run in cooperation with the state and private entrepreneurs, served also as a model and a pioneering initiative for the empire. With this project, the Ottoman government opened the way for private entrepreneurs to do business. With this comprehensive quay project, the physical conditions of the port were improved and the port could provide services according to the international standards. ${ }^{30}$

The first reflection of the project was on the loading and unloading times of the vessels. The loading and unloading time was shortened considerably; because the obligation to transport the goods to the shore using the barges was eliminated. The Ottoman official reports show that the main return times of the vessels would be reduced from 20 days to 6 days, which would also increase the gain by 300£. In addition, the profit of the traders who are in active trade relation with the port would not decrease due to damage or theft. Because products would be exposed to less handling and less severe weather conditions, thus insurance costs would be reduced. ${ }^{31}$

When the port became fully operational, the $4 \mathrm{~km}$ coastal area was incorporated into a system integrated with customs and other relevant units. It was after this structural change that different countries opened consulates in Izmir, they increased their fields of activity and

\footnotetext{
${ }^{30}$ Elie Dussaud originally planned to sell the company to the UK for $£ 500,000$ for the whole project (for quay, port complex and the reclaimed land with its buildings) in 1982. However, on that day, the company's actual value was over $£ 782,800$ or $€ 19,5$ million francs. In other words, the amount he wanted was a figure well below the value of your company. Despite this, he was not able to sell the company. The reason was that both the railway line of Izmir as well as the gas and telegraph companies were in British hands. Therefore, the British had clear dominance in the city and they did not feel uncomfortable like the French. The second reason was that Dussaud wanted to resell the company four years later in 1886, but his attempt remained inconclusive due to the concern that the French government would torpedo their relations with the Ottomans. Then, in 1887, Dussaud proposed to sell it to the Ottoman government for 440,000£ or 11 million francs, but his proposal was not deemed appropriate by the French Government. Finally in 1891, Elie Dussaud sold the Porte Dussaud to his nephew Elie Guiffraya. Since Elie Guiffraya was his nephew, Dussaud

transferred the company for a very low value of $€ 3.5$ million or £140,000. E. Frangakis-Syrett, agm., p. 31-6.

${ }^{31}$ E. Frangakis-Syrett, agm., p. 29-30.
} 
established stronger commercial ties. In this respect, Izmir was referred to as the "rising value" of the European life and commercial mobility affected all aspects of the city. ${ }^{32}$

The concessions granted by the Ottoman government to foreign companies contributed positively to the economic growth of the port. It can also be seen in the sources of that period that some important issues were negotiated within the scope the port project which activated the commercial life. Many details such as the size of the area to be reserved for free zone, the impact of ship wastes on public health and the measures to be taken for the welfare of the people were reported. The "public interest" was taken into account and the project was considered as the "first modern port on the territories of the empire". ${ }^{33}$

The success achieved in the late $19^{\text {th }}$ century, was disrupted by the political instability in the Ottoman Empire in the early years of the $20^{\text {th }}$ century. The same success was tried to be achieved again with the foundation of the Republic. The reports of the Supreme Assembly of Economics, which provide the opportunity to examine the sea shipping statistics of Izmir Port before and after the War of Independence, are very important at this point. Now, let's look again at the status of Izmir Port in the 19th century according to these reports.

\section{Izmir Port According to the Report of the Supreme Assembly of Economics}

Many of the innovations and almost all of Ataturk's principles and reforms introduced in the early period of the Republic served to a "specific purpose". "New Turkey" which came out of an all-out war in the 1920s wanted to justify "its presence" to the national and international community by making a move towards development in various fields as a requirement of the Republic regime. As one of the main sources of this study, the Supreme Assembly of Economics which was established to determine the "national economic" policy of new Turkey is an important advisory body that needs to be examined in detail.

The Supreme Assembly of Economics, established by the Law no. 1170 of 25 June 1927 and announced in the Official Gazette dated 24 July 1927, consists of 24 members. ${ }^{34} 12$ members of the assembly were selected from the Turkish Grand National Assembly. 4 members were from the chambers of commerce and industry. 2 members were farmers and the other members were as follows: 1 member from the bank, 1 from the state railways, 1 from the cooperative, 1 from the exchange market, 1 from the commodity and product exchange market and 1 from the mining sector. ${ }^{35}$ The Assembly would serve four-year terms. The duties of the Assembly were specified in Article 4 of the relevant law. Among the legitimate duties of the assembly, which did not have the power to create binding laws, were expressing opinions on the laws, bills and by-law proposed by the government on economic matters, making research on them and proposing suggestions. The Supreme Assembly of Economics, in practice, was rather involved in conducting exploratory studies. The assembly dealt with issues such as expensiveness, money and customs policies and balances of payments, and served as a bridge between the public and private sector. The assembly was a leading institution in that it prepared Turkey's first comprehensive balance of payments. The Assembly would convene every six months and for a period of fifteen days and would present the reports it prepared to the Turkish Parliament Speaker's Office; however, the decisions taken by the Assembly and the reports it prepared were not binding. ${ }^{36}$

\footnotetext{
${ }^{32}$ E. Frangakis-Syrett, agm., p. 25.

${ }^{33}$ E. Frangakis-Syrett, agm., p. 26.

${ }^{34}$ T.C. Official gazzette, No: 640, 24 July 1927.

${ }^{35}$ Official gazzette, No: 79, 21 January 1928.

${ }^{36}$ The Supreme Assembly of Economics was abolished by Article 25 of the budget law of 1935. Şengül Karadeniz Zehra Arslan, "The Situation Of Ports In Turkey During Early 1930s According to Report of Higher Council of Economy Dated as 15-29 December 1931”, Turkish Studies-International Periodical For The Languages, Literature and History of Turkish or Turkic, 8/12, 2013, p. 651.
} 
Isbank was founded in 1924 as a private bank with the aim of enlivening the capital owners and using their requests as a means of exercising power on political power. The Law for the Encouragement of Industry enacted in 1913 during the period of the ruling Committee of Union and Progress was improved further with the Law for the Encouragement of Industry enacted in 1927 and private enterprises and investment were encouraged. In addition, efforts were made to develop liberal economic policies by means of the "Supreme Assembly of Economics" established in 1927 and the "National Economy and Savings Society" established in 1929. However, when the Great Depression of 1929 coincided with the due date by which the debts of the Ottoman Empire must have been paid, it became an obligation to intervene in the economic life of the state. ${ }^{37}$

A review of the general situation of the Turkish ports in the first years of the Republic shows that the ports of the country faced many important problems. Especially in terms of technical problems, the port and quay can be said to have remained inadequate. Given the number and capacity of loading and unloading equipment used in the related period, it can be seen that the ports were not able to meet the needs. Some arbitrary applications at ports, challenging procedures of tour operations and port expenses which were considerably higher compared to foreign countries affected the development of ports adversely. ${ }^{38}$

It can be seen that the conditions where the establishment of the Supreme Assembly of Economics was required were very similar to the conditions where the Assembly of Economics was founded. The Assembly of Economics was established to guide the economy during the years of war. On the other hand, the Supreme Assembly of Economics was founded as a reflection of the state's "economic liability" at a time when the efforts were made to guide the economy hobbled after the war and to bring it back to its pre-war levels. ${ }^{39}$

In the late 1920s, some policies began to be developed to change the existing situation in Turkey which was a country exporting raw-materials and importing finished products. The economic crisis that affected the whole world known as the 1929 Depression caused the prices of raw materials Turkey exported to fall, because of the collapse in demand. The Supreme Assembly of Economics was expected to guide the economic policies through the report it would prepare and to form the basis for the "etatism" policy which would hit the headlines in the 1930s. However, the Supreme Assembly of Economics, which was not able to become an active institution that had effect on the country's economic policy like its counterparts in Europe, only engaged in advisory activities throughout its term of office. Although the Supreme Assembly of Economics did not have the power to create binding laws, it was a very important initiative in terms of thought and action. The Supreme Assembly of Economics is known to be the first organization established in the form of an "Economic Council" during the period after the proclamation of the Republic. ${ }^{40}$

Izmir Port took major hits during the years of the Independence War. The liveliness of the port fed from the commercial activities gave way to stillness. Infrastructure services and economic problems affected the port in terms of quality and quantity. Western type lifestyle and luxury spending habits that started with the Tanzimat reform era slowed down in these years. The number of commercial activities decreased since the port lost its title as the safe port, which negatively affected many areas, including daily social life in the city.

In this part of the study, the import and export statistics of the port were examined by using the reports of the Supreme Assembly of Economics specifically regarding the situation of Izmir Port. The port statistics before and after the war are remarkable in that they give an overall

\footnotetext{
${ }^{37}$ Korkut Boratav, Türkiye İktisat Tarihi (1908-2005), İmge Kitabevi, Ankara 2003.

${ }^{38}$ Primer Ministry Archive of Republic (B.C.A.), 030.10, 27.153.2.58.

${ }^{39}$ M. Koraltürk, agm., p. 47.

${ }^{40}$ F. Akın - S. Bayraktar, agm., p. 115-6.
} 
picture of the period. The effects of war can be read more clearly when this period is examined from a chronological point of view.

A review of the commercial activities that took place in Izmir Port between 1900 and 1909 shows that ship tonnages regularly increased during these years. When examined on an annual basis, it can be ascertained that commercial activities at the port came to a standstill only in 1903. In the other years, the number of activities increased. Assessment of the nine-year period reveals that the trading volume in ship tonnage amounted to approximately $100 \%$ between 1900 and 1909. It can be clearly seen from the figures that the Port of Izmir continued developing even in this troubled period when the Ottoman Empire, which came out of the 18771878 Ottoman-Russian War, was dealing with the problems of the nationalist movements in the Balkans and the debates on the constitutionality were exacerbated inside the empire. The postwar period shows that Izmir Port was not able to recover, just as the "New Turkey", and the trading volume rate of the port remained below the rates in the 1900s (Table 2). ${ }^{41}$ The country, which did not recover its economy yet, was hit by the crisis known as the 1929 Depression, which started with the collapse of the American Stock Market, and encountered a second obstacle on the way to progress. ${ }^{42}$

Table 2. Izmir Port's Ship Operations Before and After World War I

\begin{tabular}{lccccc}
\hline \multicolumn{2}{c}{ Before World War I } & \multicolumn{2}{c}{ After World War I } \\
\hline Year & $\begin{array}{c}\text { Ship tonnages } \\
\text { (million) }\end{array}$ & Year & $\begin{array}{c}\text { Ship tonnages } \\
\text { (million) }\end{array}$ & Year & Ship tonnages (million) \\
\hline 1900 & 1,566 & 1905 & 2,340 & 1926 & 1,913 \\
1901 & 1,908 & 1906 & 2,370 & 1927 & 1,740 \\
1902 & 2,098 & 1907 & 2,352 & 1928 & 2,054 \\
1903 & 2,024 & 1908 & 2,819 & 1929 & 1,995 \\
1904 & 2,215 & 1909 & 2,890 & 1930 & 1,843 \\
\hline
\end{tabular}

Assessment of the situation of Turkish ports until World War I shows that Izmir Port, which was considered as Turkey's second largest port since it was the center for exporting products such as tobacco, grapes and figs, has always been the number one port in terms of maritime trade. ${ }^{43}$ The Supreme Assembly of Economics recorded the goods exported through Izmir Port and the statistical data on these goods and presented them in a table (Table 3). ${ }^{44}$

Table 3. Goods Exported from Izmir Port in 1929 and Their Price

\begin{tabular}{ccc}
\hline Exported Goods & Amount (Ton) & Price (Million Lira) \\
\hline Grape & 42,000 & 17,4 \\
Fig & 23,800 & $8,-$ \\
Tobacco & 19,000 & $26,-$ \\
Cotton & 3,500 & 8,7 \\
Opium & 11,212 & $5,-$ \\
Acorn & 36,000 & $3,-$ \\
Olive oil & 7,200 & 4,5 \\
Carpet & - & 4,6 \\
Licorice & 15,100 & $1,-$ \\
Barley & 2,300 & 0,195 \\
\hline
\end{tabular}

\footnotetext{
${ }^{41}$ B.C.A.,030.10, 27.153.2, 56.

${ }^{42}$ B.C.A.,030.10, 27.153.2, 54.

${ }^{43}$ B.C.A.,030.10, 27.153.2, 59.

${ }^{44}$ B.C.A.,030.10, 27.153.2, 57.
} 
The second important thing that is understood from the table is that almost all of the products are unique to Izmir and its surroundings. We can also see that products belong to the Aegean Region were exported as hinterland..$^{45}$ Prices of the goods exported from the port before and after the war were also calculated and presented in the report (Table 4). ${ }^{46}$

Table 4. Values of Imports-Exports through Izmir Port Before and After World War I

\begin{tabular}{ccc}
\hline & Values of Imports-Exports Before World War I \\
\hline Year & $\begin{array}{c}\text { Export Value } \\
\text { (Million Gold) }\end{array}$ & $\begin{array}{c}\text { Import Value } \\
\text { (Million Gold) }\end{array}$ \\
\hline $\mathbf{1 9 1 0}$ & 6.9 & 5.5 \\
$\mathbf{1 9 1 1}$ & 7.1 & 5.5 \\
$\mathbf{1 9 1 3}$ & 7.2 & 5.8 \\
\hline \multicolumn{3}{c}{ Values of Imports-Exports After World War I } \\
\hline $\mathbf{1 9 2 6}$ & 60.7 & 33.5 \\
$\mathbf{1 9 2 7}$ & 92.1 & 33.3 \\
$\mathbf{1 9 2 8}$ & 75.4 & 34.4 \\
$\mathbf{1 9 2 9}$ & 80.8 & 38.6 \\
\hline
\end{tabular}

When the data presented in the table are analyzed, it can be seen that the export and import figures between 1910-1913 are balanced. The valuation of the goods based on the value of gold helps us better understand the importance of the goods exported from Izmir Port in the country's economy. In Turkey, which was an agricultural country at that time, the share of goods exported in the total budget of the country was large. It is worth noting that the goods exported from Izmir and the surrounding ports were balanced with the imported goods. Likewise, a review of the statistics between 1926 and 1929 shows the effects of the "worldwide economic depression". Considering the statistical value of the figure reached in 1927, it is seen that a different momentum was gained compared to the previous year and the following two years. When evaluated in terms of export and import rates, it can be seen that there is $50 \%$ difference compared to the pre-republic period.

\section{Conclusion}

Izmir has always been an important port city throughout history due to its geo-strategic position. As one of the major junction points connecting Asia and Europe, Izmir attracted the attention of Venetian and Genoese merchants, who were always one step ahead in maritime trade. It is known that it was these merchants who laid the first structural bases of Izmir and Foca ports and dominated the maritime trade for a long time.

Izmir has been in a unique position since the first years that it was included in the Ottoman territories with its demographic structure, cultural texture and synthesis of East and European life. After the $16^{\text {th }}$ century, when the Ottoman Empire focused on maritime trade, Izmir succeeded to be popular with its natural harbors and convenient hinterland. The fertile lands in the region, the convenience of road transportation and being the final destination of the Silk Road can be seen as the advantages of the city.

The first detailed information about Izmir Port is available in Piri Reis' book titled Kitâbi Bahriye. Kitâb-i Bahriye is both a source for geography and maritime trade. The attention paid by Piri Reis, his methodology, and his efforts to map the places he saw and described can be seen as a success of his work. The facilities and physical conditions of the Izmir Port in the $16^{\text {th }}$ century as well as the geographical characteristics of the region such as climate and fresh water resources were given thoroughly in the book, and almost all the information required for a

\footnotetext{
${ }^{45}$ B.C.A.,030.10, 27.153.2, 56.

${ }^{46}$ B.C.A., $030.10,27.153 .2,58$.
} 
mariner was meticulously documented. Although Piri Reis mentions in his book about imports and exports at the port, he does not dwell on the socio-economic and political dimensions of the port that affect the city life. Addressing the 19th-century panorama of Izmir Port from a different point of view, Sibel Zandi Sayek filled the missing parts of the Piri Reis’ book.

She discusses the Ottoman Izmir in her book which she wrote as a city monograph. Sayek tells the reflection of the life that changed with the Tanzimat reform era on Izmir with a broad perspective. She particularly points out the civil rights of non-Muslims after the Tanzimat reform era, the enlargement of the commercial structure and the ever-growing capacity of the international port as well as highlighting that the port served as the door of the Ottoman Empires opening to the West. In parallel with the port trade, Izmir developed a new corporate identity in this period and became the center of a lively and vibrant life. The port was structurally expanded and developed through the "build-operate-transfer" model, helping the port gain significant momentum in terms of commercial volume.

Although Izmir Port was a commercial center during the last years of the Ottoman Empire, the commercial aspect of the port faded in the first years of the Republic. The war economy affected maritime trade just like any other field. From this point of view, we can see that the Ottoman Empire was faced with negative life conditions during the period that started with the Balkan War and ended with the War of Independence. Along with the newly founded Republic, we see that various principles and reforms were accepted and new moves were made in order to revive and restore the Anatolia. We know that the certain institutions and organizations established especially for economic development assumed important roles during this period. One of these institutions was the Supreme Assembly of Economics. As an advisory body, this assembly served to develop a road map for the government and came up with important findings. One of the most important works of the Assembly is the report on Izmir Port. The report is very detailed and important. Including comparative and statistical information, this report is also valuable in that the data presented in the report relies on valid documents. The Assembly's report was mostly based on more numerical data.

Piri Reis's work mostly contains geographic and oceanographic information, while Sayek's work deals with the social fabric of the port and port city. On the other hand, the Supreme Assembly of Economics revealed statistical information and addressed more specific aspects of the port. This study aims to offer a synthesis of three different perspectives on the Port of Izmir during the period from the $16^{\text {th }}$ century to the early years of the Republic and to contribute to the field of maritime industry.

\section{Bibliography}

Acartürk, Ertuğrul, Kılıç, Ramazan, "The Analysis of the Capitulations in the Ottoman Empire from a Economic and Political Perspective”, Hacettepe University Journal of Economics and Administrative Sciences, 29/2, 2011, p. 1-21.

Akın, Fehmi, Bayraktar, Serkan, "One of the Economics Institutions of the Early Republic: High Economic Council”, Dumlupinar University Journal of Social Sciences, 29, 2011, p. 115-6.

Arı, Kemal, "İzmir'de Deniz Ulaşımı ve Ticaretinin Kent Kimliğinin Oluşumu Üzerindeki Etkileri”, Dokuz Eylül University Maritime Faculty Journal, 3/1, 2011, 1-18.

Arı, Kemal, "Türk Deniz Ticareti Tarihi Sempozyum V: Piri Reis-Turkish Maritime Trade History Symposium V: Piri Reis” Journal Of Modern Turkish History Studies, 13/26, 2013, p. 301-15.

Boratav, Korkut, Türkiye İktisat Tarihi (1908-2005), İmge Kitabevi, Ankara 2003. 
Bostan, İdris, "Kadırga'dan Kalyon'a: XVII. Yüzyılın İkinci Yansında Osmanlı Gemi Teknolojisi'nin Değişimi”, Osmanlı Araştırmaları (The Journal of Ottoman Studies), 24, 2004, p. 66-86.

Bostan, İdris, Beylikten İmparatorluğa Osmanl Denizciliği-Ottoman Marine Activities from Beylik to Empire, Istanbul 2015.

Epstein, M, The Early History of The Levant Company. New York 1981.

Girgin, Güneş, "Mediterranean Trade in Phoenicians", Selçuk University Graduate Schhool of Social Sciences, Konya 2006.

Google. "Google Privacy Policy.”, https://www.biyografi.net.tr/piri-reis-kimdir/, date accessed 28.03.2018.

Karadeniz, Şengül, Arslan, Zehra, "The Situation Of Ports In Turkey During Early 1930s According to Report of Higher Council of Economy Dated as 15-29 December 1931”, Turkish Studies-International Periodical For The Languages, Literature and History of Turkish or Turkic, 8/12, 2013, p. 649-62.

Koca, Nemlioğlu, Yasemin, "Pîrî Reis Eserlerinde Liman Şehirlerinin Özellikleri”, Paper presented at the International Symposium 'Piri Reis and History of Turkish Maritime, Ankara, 2014, p. 135-48.

Koraltürk, Murat, “Âli İktisat Meclisi (1927-1935) (Higher Council of Economy 1927-1935)”, Ekonomik Yaklaşım (Financial Approach), 7/23, 1996, 47-64.

Primer Ministry Archive of Republic (B.C.A.). Âli İktisat Meclisi Raporlart-The Supreme Assembly Of Economics. Ankara: Başvekâlet Müdevvenat Matbaası, 1933.

Reis, Piri, Kitâb-i Bahriye. Edited by Ertuğrul Zekai Ökte. Translated by Vahit Çabuk and Tülay Duran, Türkiyre Teknoloji Takımı Vakfi-Turkey Technology Team Foundation (TTT), Vol. 1, Istanbul 1988.

Serbestoğlu, İbrahim, "Ottoman Nationality Law as an Example of a Forced Modernization”, Osmanlı Tarihi Araştırma ve Uygulama Merkezi Dergisi OTAM, 29, 2011, p. 205.

Topdemir, Hüseyin Gazi, “Bilim Tarihçisi Gözüyle Piri Reis”, TUBA Günce, July 45, 2013.

Yaktı, Özlem, Ünlü Soylu, Perihan, "A Pioneering Consultation Organ On The Path of Economic Development: Supreme Assembly of Economics”, Ankara University Institue of Turkish Revolution History Journal of Atatürk Yolu, 47, 2011, p. 80.

Yıldız, Muharrem, "İzmir Levantenleri Üzerine İnceleme", TURAN: Stratejik Arastirmalar Merkezi, 4/13, 2012, p. 36-54.

Zandi-Sayek, Sibel, “Ottoman İzmir The Rise of a Cosmopolitan Port, 1840-1880”, University of Minnesota Press, Minnesota 2012.

\section{Official Puplications}

T.C. Official Gazzette, No: 640, 24 July 1927.

T.C. Official Gazzette, No: 79, 21 January 1928.

Primer Ministry Archive of Republic (B.C.A.)

B.C.A., 030.10, 27.153.2, 54.

B.C.A., 030.10, 27.153.2, 56.

B.C.A., 030.10, 27.153.2, 57.

B.C.A., 030.10, 27.153.2, 58.

B.C.A., 030.10, 27.153.2, 59. 